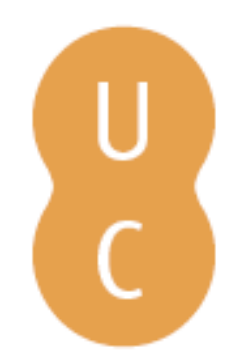

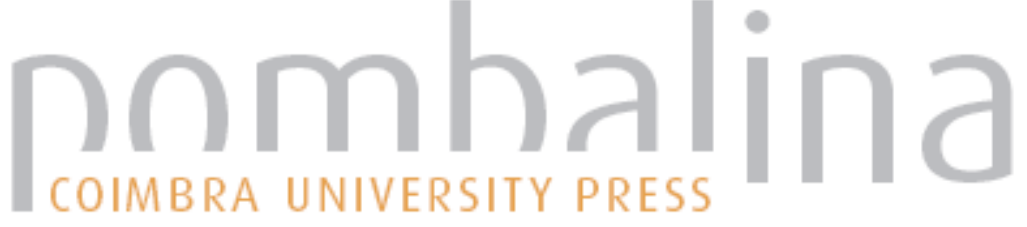

\section{The Greek National Observatory of forest fires}

Autor(es): $\quad$ Gitas, loannis; Zalidis, George; Eftychidis, George

Publicado por: Imprensa da Universidade de Coimbra

URL

persistente: URI:http://hdl.handle.net/10316.2/34134

DOI: $\quad$ DOI:http://dx.doi.org/10.14195/978-989-26-0884-6_194

Accessed : $\quad$ 26-Apr-2023 07:13:02

A navegação consulta e descarregamento dos títulos inseridos nas Bibliotecas Digitais UC Digitalis, UC Pombalina e UC Impactum, pressupõem a aceitação plena e sem reservas dos Termos e Condições de Uso destas Bibliotecas Digitais, disponíveis em https://digitalis.uc.pt/pt-pt/termos.

Conforme exposto nos referidos Termos e Condições de Uso, o descarregamento de títulos de acesso restrito requer uma licença válida de autorização devendo o utilizador aceder ao(s) documento(s) a partir de um endereço de IP da instituição detentora da supramencionada licença.

Ao utilizador é apenas permitido o descarregamento para uso pessoal, pelo que o emprego do(s) título(s) descarregado(s) para outro fim, designadamente comercial, carece de autorização do respetivo autor ou editor da obra.

Na medida em que todas as obras da UC Digitalis se encontram protegidas pelo Código do Direito de Autor e Direitos Conexos e demais legislação aplicável, toda a cópia, parcial ou total, deste documento, nos casos em que é legalmente admitida, deverá conter ou fazer-se acompanhar por este aviso. 


\section{ADVANCES IN}

Forest Fire

\section{RESEARCH}

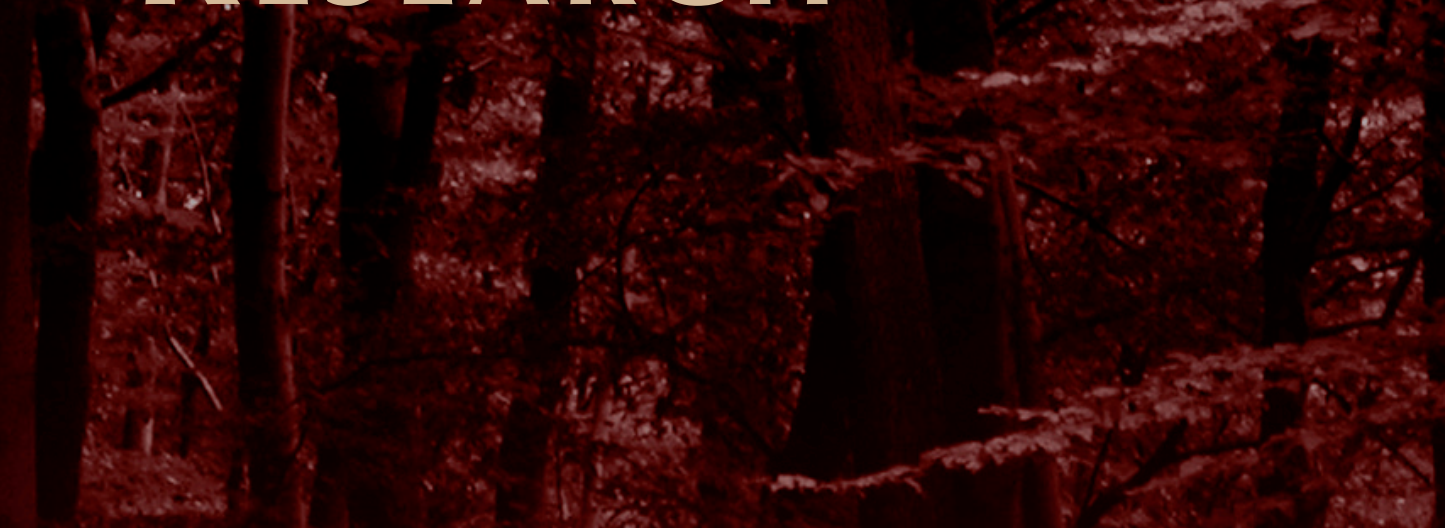

\section{DOMINGOS XAVIER VIEGAS}

\section{EDITOR}




\title{
The Greek National Observatory of forest fires
}

\author{
Ioannis Gitas ${ }^{\mathrm{a}}$, George Zalidis ${ }^{\mathrm{b}}$, George Eftychidis ${ }^{\mathrm{b}}$ \\ ${ }^{a}$ Aristotelian University of Thessaloniki-AUTH, Thessaloniki, Greece (igitas@for.auth.gr) \\ ${ }^{b}$ Interbalkan Environment Center; Loutron 18, 57200 Thessaloniki, Greece (zalidis@balcenv.gr; \\ g.eftychidis@gmail.com)
}

\begin{abstract}
The Greek Forest Service has recently established the National Observatory of Forest Fires (NOFF) in collaboration with the Laboratory of Forest Management and Remote Sensing, Aristotle University of Thessaloniki (AUTH) and the Interbalkan Environment Center (i-BEC). The purpose of the i-BEC is to support the systematic monitoring of the quality of the environment in Greece, the assessment of potential risk related to natural hazards and the development of relevant technology and sound knowledge, applicable in the Balkan region. A series of indicators and decision support applications is used for the monitoring of selected environmental parameters in real time in order to support operational early warning and documented risk assessment.
\end{abstract}

Keywords: National Observatory, wildfire, forest fire, risk assessment, Balkans, fire management

\section{The problem targeted}

The adverse effects of forest fires can be prevented, or at least minimised, by implementing successful prevention, suppression and mitigation measures. The design and consequent success of such measures is highly dependent on the availability and reliability of up-to-date fire-related data, such as burned area or fire risk maps. Such data are often collected locally and inconsistently in order to be used in context of independent projects; hence, they can rarely be found in a consistent format and content over extensive areas. The lack of such data inhibits the capacity of designing successful measures at regional or national scales. This is also the case in Greece, despite the capacity brought by new technologies and the progress made during the last decades in the topics of fire risk assessment, fire modelling and spatial data management. The quality, completeness and reliability of the fire data in Greece is still questioned due to lack of operational and procedural standardization and data interoperability.

NOFF aims to collect various environmental data related to forest and fire management and to develop a series of modern products and services that will support the design of efficient forest fire prevention policies in Greece and the Balkan region, as well as the assessment of the fire impact. The observatory aims to become the focal point in Greece and a major Center in the Balkan region in handling forest fire related information.

\section{Products and services}

A number of different activities are planned for the following years including the development of a number of spatial products, information tools and fire management support services aiming to support all Balkan countries, the creation of the Greek forest fire web-portal, an early warning service, as well as dissemination and capacity building actions.

Currently, the development of the following products and services is in progress:

- A consistent methodology for mapping the forest fuel types occurring in the Balkan region.

- A fire risk index adapted to the soil, climate and vegetation peculiarities of the region. 
- A methodology for the accurate mapping of burned areas using high resolution satellite imagery, which will be delivered within a service that can provide burned area maps on a yearly base or on demand.

- An interactive Fire Forest portal and associated mobile applications which will make the products and services of NOFF available to stakeholders, policy makers, and local and regional authorities.

The aforementioned products will be designed for operational use and they will be tested in cooperation with relevant public services. The developed tools are planned to have graphical and multilingual user interface that could be easily employed by experts in all Balkan countries. The rest of this section details the aforementioned products.

\subsection{Forest fuel type mapping}

Forest fuel maps are primarily used by fire behaviour simulation models, in order to accurately perceive and assess the risk, severity, propagation and environmental impact of forest fires. The developed methodology would have to be able to regularly map forest fuels over extensive areas at a low cost so that its operational use will be feasible. Towards this end, it will benefit from the experience already gained by previous forest fuel mapping projects (e.g. ArcFuel and FUELMAP) and minimise the need for costly field data collection, by primarily relying on the processing of readily available ancillary data — consistently available across the Balkan countries — and remotely sensed images.

The combined use of ancillary data, such as the CORINE land-cover map and the Joined Research Centre (JRC) forest type map, will allow the mapping of certain forest fuel types. The remaining forest fuel types will be mapped by processing remotely sensed images using object-based image analysis (OBIA) and advanced image classification algorithms (fuzzy rules, decision trees, support vector machines). These images will be collected during the summer and winter seasons by a Disaster Monitoring Constellation (DMC) sensor at a $22 \mathrm{~m}$ spatial resolution. Images from both seasons will be used to facilitate the distinction between forest fuels which display different seasonal behaviour, such as evergreen and deciduous tree species.

The methodology will initially be applied over the prefecture of Chalkidiki, which is located in northern Greece and extents over an area of about $2900 \mathrm{~km} 2$ covered by a representative range of forest fuel types found across Greece. The resulting forest fuel map will be validated with a series of field visits.

\subsection{Fire risk index}

An efficient index for mapping forest fire risk is currently being developed. The fire risk index will be computed based on soil, climate and vegetation peculiarities of the region. The production of the fire risk index takes advantage of the use of Landsat 8 images that are freely and regularly distributed over the internet, being thus capable to provide seasonal assessment of fire risk based on deviation from normal vegetation, topographic and meteorological conditions. The calculation of the fire danger index will be adjustable to local data, thus being easily applicable to the different countries of the region. The operational fire risk index will be linked online via SMS and e-mail with the Greek Special Secretariat of Forests and the local forest services. For the creation of this index an algorithm will be developed that also takes into account historical weather data and the fire regime of each area. The final value will be weighted by a set of selected parameters and the development and the accuracy assessment of the fire danger index will be applied at the Region of Central Macedonia.

\subsection{Burned area mapping}

An in-house method for the accurate mapping of burned areas is currently being developed, using high resolution satellite imagery. The method can be used operationally at several scales (local, regional and national). The employed methodology will be implemented in two stages: 
- Initially, the satellite image will be segmented through the application of an object-based image analysis (OBIA) technique. A number of higher order features will be extracted from the original image (on an object level basis) and a set of prototype reference objects will be selected by the user.

- Subsequently, a small subset of highly informative features will be determined through the application of an advanced feature selection methodoly, based on the principles of the so-called Fuzzy Complementary Criterion (FuzCoC). The burned area map will be produced by employing a Support Vector Machine (SVM) classifier on the selected feature subset, which presently constitutes one of the most accurate classification techniques based on supervised learning.

The first stage will be employed using a well-known commercial image processing software. For the second stage, a custom user interface is being developed, which will be used to apply the feature selection method and subsequent classification with minimum user interaction.

The employed method, which is sensor independent, is normally applied for mapping older fires, but it can also be used operationally to map new fires as well as for the reconstruction and mapping of historical events and the assessment of the fire regime. Initially, the methodology will be employed and validated in two areas of Greece recently affected by fires (Parnitha and Rhodes), using two IKONOS very high resolution satellite images. Ultimately, the whole methodology will be delivered within a service which will provide burned area maps on a yearly base or on demand.

\subsection{Web portal and applications}

A Forest Fire web portal will be created with the purpose of disseminating the NOFF's products and services to stakeholders, policy makers, and local and regional authorities. It will be accessible through a web browser and allow interested parties to visualise and interact with the maps and tools provided by NOFF through a friendly user interface. Thus, users will be able to benefit from what NOFF has to offer without the need to install and operate specialised and expensive software or a deep understanding of forest fire science. The portal will also host a depository for fire related data that will accommodate the data exchange within the scientific community and promote research.

In addition to the above, the Forest Fire web portal is planned to include a Public Participation GIS (PPGIS) that will bring the academic practices of GIS and mapping to the local level in order to support transfer of knowledge and promote the development of new knowledge. The idea behind PPGIS is to use and produce digital maps, satellite imagery, sketch maps, and many other spatial and visual products and tools in order to promote geographic involvement and awareness on a local level. Apart from the PPGIS, the Forest Fire portal will include the frequently updated map of fire risk and the most updated map of forest fuel types.

A number of mobile applications (SMS alerts, smart phone application) are anticipated for the ubiquitous access to the data resources as well as for distributing information and relevant early warning messages related to the level of fire risk to pertinent fire management groups including the Forest Service and Fire Service personnel.

\section{Main results}

Apart from the networking and capacity building objectives, the results expected from the establishment of NOFF are related to the integration of scientific knowledge and technological tools in the operational practice of fire prevention and forest protection. A series of mapping products and a suite of EO data processing services will be available through the NOFF to all Balkan countries, thus providing several opportunities for scientific cooperation among the neighbouring countries. The forest fuel map, the Fire Danger Index and the Burned area mapping service are the key results that 
NOFF delivers. Furthermore a web repository of fire management data and information related to this region of Europe will be also developed.

\section{Conclusions}

The objective of the NOFF is to develop and promote the aforementioned fire management information products and services to interested parties and forest fire stakeholders both at national and a regional (Balkan region) level. This will be accomplished through the organisation of workshops, seminars and short courses that will ensure the optimization of use and performance of the products and services described above. The aim of NOFF is to become a regional center of fire management technology and information, providing the background for organizing relevant inter-Balkan activities with the participation of fire experts and potential end-users from different Balkan countries. 